Research Product 96-02

\title{
Annotated Bibliography of Training Technologies and Methods for Teaching the Use of Advanced Technology
}

\author{
Joel W. Collins III and May H. Throne \\ University of Louisville
}

\section{Armored Forces Research Unit Barbara A. Black, Chief}

U.S. Army Research Institute for the Behavioral and Social Sciences 5001 Eisenhower Avenue, Alexandria, Virginia 22333-5600

Office, Deputy Chief of Staff for Personnel

Department of the Army

January 1996 